\title{
Prevalence of Helicobacter pylori Infection in Warao Lineage Communities of Delta Amacuro State, Venezuela
}

\author{
Diana Ortiz/+ , María Eugenia Cavazza, Orquídea Rodríguez, Isabel Hagel, MaríaCorrenti*, \\ Jacinto Convit
}

\begin{abstract}
Instituto de Biomedicina, Ministerio de Salud y Desarrollo Social, Universidad Central de Venezuela, Apartado Postal 4043 , Caracas 1010A, Venezuela *Instituto de Oncología y Hematología, Ministerio de Salud y Desarrollo Social, Caracas, Venezuela
\end{abstract}

The purpose of this study was the evaluation of Helicobacter pylori infections in children and adults from two indigenous communities of Delta Amacuro State, Venezuela, that differ in hygienic conditions of the housing. The evaluation was performed in 98 children (mean age $7 \pm 3.37$ years) and their mothers (33.96 \pm 13.77 years) from two communities of Warao lineage. Anti-H. pylori serum $\operatorname{IgG}$ and secretory anti-H. pylori IgA antibodies were determined, as well as total secretory IgA and $\mathrm{H}$. pylori antigens in feces. Serological prevalence of $\mathrm{H}$. pylori infection was $38 \%$ in children and $84 \%$ their in mothers. Children from the community that had the most deficient sanitary and hygienic conditions had significantly lower titers of specific IgG antibodies and total secretory IgA $(P<$ $0.0001)$ and a high percentage of them had $\mathrm{H}$. pylori antigens in their feces $(P<0.0001)$. The levels of specific IgA were similar in both groups. The results indicate that in these populations there is a high prevalence of $\mathrm{H}$. pylori infection and that poor hygienic conditions can increase the risk of infection and damage to the gastrointestinal tract.

Key words: Helicobacter pylori - secretory IgA - seroprevalence - Venezuela

Helicobacter pylori colonizes about $50 \%$ of the world population; less than $20 \%$ of affected individuals develop gastroduodenal diseases. Gastroduodenal diseases associated with $H$. pylori occur mainly in adults. Nevertheless, the infection is usually acquired during childhood (Wotherspoon et al. 1993) and it is possible that the humoral and mucosal tissue responses at that time can determine the natural course of the infection (Torres et al. 2000).

Although studies suggest that the majority of individuals acquire $H$. pylori in childhood, the microoganism can persist in its gastric habitat for decades. It is acquired from another family member (Brenner et al.1999, Rothenbacher et al.1999). During this time, it can undergo considerable genetic changes that could facilitate adaptation to the gastric ecosystem of a particular host, including changes in environmental features brought about by H. pylori colonization (Falk et al. 2000). H. pylori isolates from un related individuals have totally different genetic fingerprints, so that $H$. pylori can be considered a "quasi-species" (Covacci et al. 1997).

It has been reported at a worldwide level that $\mathrm{H}$. pylori infection prevalence in children varies between $10 \%$ and $80 \%$ (Vaira et al. 1994, Torres et al. 2000). The lowest

This investigation was financed by Conicit Project S1-96001408, and by the Program for Special Attention to Indigenous Populations, coordinated by General Victor Salom the National Guard of Venezuela.

${ }^{+}$Corresponding author. Fax: +58-212-861.8670. E-mail: dprincz@hotmail.com

Received 5 July 2002

Accepted 14 July 2003 prevalence has been found in populations in Northern and Eastern Europe, Japan and other parts of Asia. High prevalence has been well documented in India and Bangladesh and in certain cities of Africa and Latin America (Torres et al. 2000).

In a study where prevalence by ethnic category was examined, an increase in immigrant groups from high prevalence regions was reported, as well as in low socioeconomic level ethnic risk groups (Ma et al. 1998, Vorobjova et al. 2000). Again increase with age, low socio-economic and educational levels, race, crowded living quarters, migration from high prevalence regions, background of H. pylori-infected family members, poor nutritional state indicators, ingestion of water and vegetables which do not fulfill hygienic conditions, have been reported as risk factors for the increase of $H$. pylori infection (Graham et al. 1991, Smoat et al. 1994, Torres et al. 2000).

Few studies have examined the incidence of $H$. pylori infection in children, possibly due to the ethical considerations involved in carrying out invasive tests which are not really required in these age groups. On the other hand, studies in indigenous communities are troublesome to carry out because of the difficulties of both physical and cultural accessibility. The main purpose of this study was the evaluation of $H$. pylori infection in children and adults from two indigenous communities of Delta Amacuro State in Venezuela.

\section{MATERIALS AND METHODS}

Study population - Ninety-eight children, males and females with ages between 1 and 14 years (average $7 \pm$ 3.37 years) and 32 adult women ( $33.96 \pm 13.77$ years) from two indigenous communities of Warao lineage, Pedernales municipality, Delta Amacuro State, were evaluated (Table I). This state has a tropical rainy climate and swampy grounds of the tropical hydromorphic type. Its com- 
TABLE I

Age and sex of the groups of children from two indigenous communities in Delta Amacuro State

\begin{tabular}{lccc}
\hline Community & $\begin{array}{c}\text { Females } \\
(\%)\end{array}$ & $\begin{array}{c}\text { Males } \\
(\%)\end{array}$ & $\begin{array}{c}\text { Age } \\
(\mathrm{x} \pm \mathrm{sd})\end{array}$ \\
\hline Isla Misteriosa $(\mathrm{n}=38)$ & 48 & 52 & $5.5 \pm 3.03^{a}$ \\
Playa Sucia $(\mathrm{n}=60)$ & 47 & 53 & $7.9 \pm 3.26$ \\
Isla Misteriosa and Playa & 48 & 52 & $7 \pm 3.37$ \\
Sucia $(\mathrm{n}=98)$ & & &
\end{tabular}

$a: \mathrm{p}<0.001$

munities are dispersed along the banks of the Orinoco River Delta, living mainly from hunting and fishing.

The study protocol was approved by the Ethics Committee of the Institute de Biomedicine, Faculty of Medicine of Universidad Central de Venezuela, and by competent authorities of Delta Amacuro State.

The characteristics of the studied population were compared with values obtained from non-indigenous, noninfected Venezuelan groups that live under adequate hygienic conditions.

Serum determination of $\operatorname{Ig} G$ to $H$. pylori - The determination of specific IgG antibodies was done using a commercial immunoenzymatic kit (PYLORISET EIA-G, ORION Diagnostic Laboratories). The plates were read in a spectrophotometer at $405 \mathrm{~nm}$ and the optical density units were extrapolated in a graph on semi-logarithmic paper, using as reference the standards supplied with the kit. The results obtained were expressed in antibody titers (positive titers $>300$ ).

Determination of secretory IgA to H. pylori in saliva - Specific secretory anti-H. pylori IgA in saliva was determined using an ELISA technique standardized in our laboratory. For this purpose we collected saliva from each subject directly from the mouth. The samples were kept in vacutainer tubes with ethylenediaminotetracid (EDTA) at $-20^{\circ} \mathrm{C}$ until use. The polystyrene plates (Nunc MaxiSorp) were sensitized with the $H$. pylori antigen $(2.5 \mu \mathrm{g}$ per well) diluted in coating buffer $\mathrm{pH} 9.6$ during $2 \mathrm{~h}$ at $37^{\circ} \mathrm{C}$. Nonspecific sites were blocked with $0.5 \%$ PBST-BSA during $2 \mathrm{~h}$ at $37^{\circ} \mathrm{C}$, then the saliva samples were incubated during $1 \mathrm{~h}$ at $37^{\circ} \mathrm{C}$ at a $1: 10$ dilution in $0.5 \%$ PBST-BSA. The conjugate was peroxidase-labeled anti-IgA (SIGMA) diluted 1:1000 in 5\% PBST-BSA. After incubation at $37^{\circ} \mathrm{C}$ for $1 \mathrm{~h}$, the reactions were developed with o-phenylenediamine (SIGMA) and $\mathrm{H}_{2} \mathrm{O}_{2}$, reading at $492 \mathrm{~nm}$ absorbance. Values 0.300 units of optical density were considered positive; this cut-off was determined in previous studies (Ortiz et al. 2001).

Antigen preparation - A crude antigen prepared from five strains isolated from patients with duodenal ulcer (DU) and H. pylori infection confirmed by the four conventional criteria was used. The H. pylori strains isolated were inoculated in chocolate and blood cultures mediums and the harvesting of the microorganisms was done by adding $2 \mathrm{ml}$ of sterile PBS to the agar plates and harvesting the bacteria. The harvested bacteria were centrifuged at $2000 \mathrm{rpm}$ to obtain a pellet, which was washed $2 \mathrm{x}$ with PBS. The cells were then submitted to 5 sonication cycles of $30 \mathrm{~s}$ each, then the samples were centrifuged at $14000 \mathrm{rpm}$ in an Eppendorf centrifuge and the protein concentration of the supernatant was determined by the Lowry method (Lowry et al. 1951). SDSpolyacrilamide $(10 \%)$ gel electrophoresis was carried out with the cell sonicate to visualize the protein bands. For this purpose it was diluted in sample buffer (Tris HCL $0.06 \mathrm{M}, \mathrm{pH} 6.8,2 \%$ SDS, $10 \%$ glycerol, $5 \%$ 2-mercaptoethanol, $0.001 \%$ bromophenol blue).

Determination of total secretory IgA in saliva - To determine total secretory IgA in saliva we used the ELISA technique previously described (Ortiz et al. 2001).

Determination of H. pylori antigens in feces - For the determination of $H$. pylori antigens in fecal material we used a commercial qualitative immunoenzymatic diagnostic method (PREMIER PLATINUM HpSA Kit, Meridian Diagnostic, Inc.) and the plate was read at 450 $\mathrm{nm}$ absorbance. Samples with absorbance values less than 0.140 were considered negative, those with values between 0.140 and 0.160 were regarded as ambiguous, and those with results equal to or greater than 0.160 were reported as positive.

Statistical analysis - The geometric means and standard deviations of the titers of specific IgG antibodies were calculated, as well as the total and specific secretory IgA. The various groups were compared using Student's $\mathrm{t}$ test, and the differences among proportions were compared applying the Chi-square $\left(\chi^{2}\right)$ test.

\section{RESULTS}

Regarding the immunological parameters studied in the children, we found a prevalence of positive tests for humoral H. pylori $\mathrm{IgG}$ antibodies of $38 \%$ (828 \pm 583 titers); the titers were significantly more elevated in the Playa Sucia community than in Isla Misteriosa $(\mathrm{p}<0.0001)$. The mean value of total secretory IgA in saliva was significantly higher $(\mathrm{p}<0.001)$ in children from the Playa Sucia community than in those of the Isla Misteriosa community. Nevertheless, secretory IgA to $H$. pylori values in saliva were similar in both groups $(0.47 \pm 0.22$ OD), above the cut off established for children not infected by $H$. pylori. The evaluation of the presence of $H$. pylori antigens in feces, showed a positivity of $95 \%$ in children from Isla Misteriosa, compared to $10 \%$ in the Playa Sucia group (Table II).

When studying the group of women, we found $84 \%$ of seroprevalence of H. pylori infection, $(2288 \pm 2005$ specific IgG titers). The values of total secretory IgA were also measured $(0.82 \pm 0.32 \mathrm{OD})$ and the values of secretory IgA to $H$. pylori in saliva $(0.57 \pm 0.21 \mathrm{OD})$ were significantly higher $(\mathrm{p}<0.05)$ than the value obtained of adults not infected by $H$. pylori. This values were significantly higher $(\mathrm{p}<0.0001)$ in mothers that in the children.

An increase of total and specific secretory IgA to $H$. pylori (Fig. 2) measured in saliva, as well specific IgG antibodies (Fig. 1a,b), were observed with age progression. Seroprevalence of infection increased with age, and the highest titers were seen at age 40 , with a decrease from that age on. The total secretory $\operatorname{IgA}$ and specific secretory IgA to $H$. pylori in relation to age, appeared to stabilize from 35 years on (Fig. 2). 


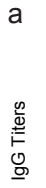

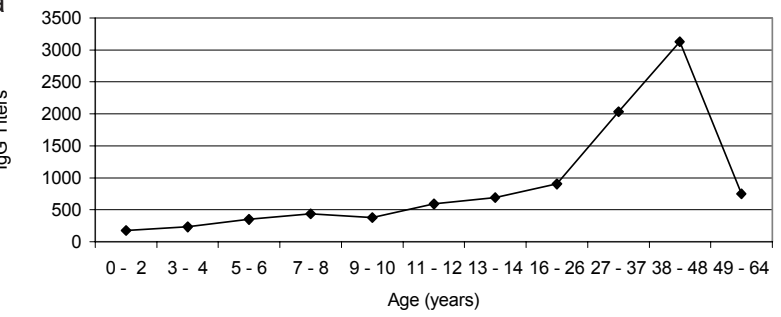

b

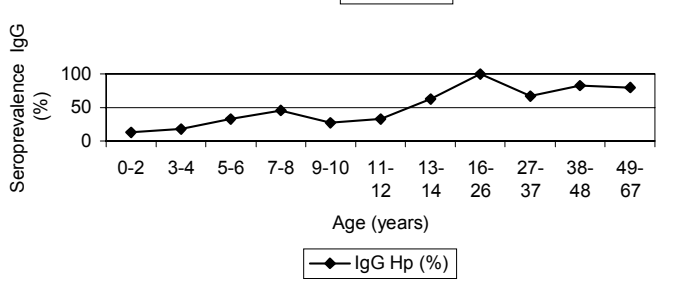

Fig. 1- a: IgG titers to Helicobacter pylori according to age; b: seroprevalence of $\operatorname{IgG}$ to $H$. pylori according to age.

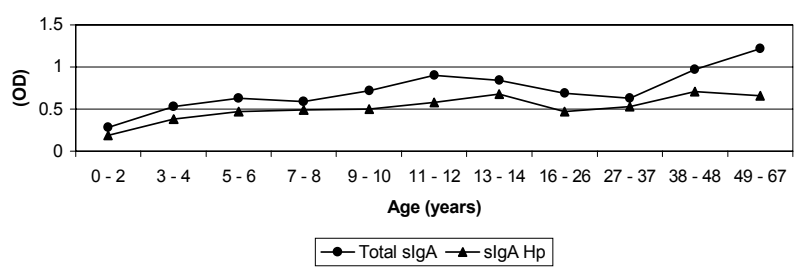

Fig. 2: levels of total secretory $\operatorname{IgA}$ and secretory $\operatorname{IgA}$ to Helicobacter pylori in saliva according to age.

\section{DISCUSSION}

In our country there is a high prevalence of $H$. pylori infection in adults and children (Piñero et al. 2000, Ortiz et al. 2001). In spite of the fact that there are many reports on the prevalence of infection with this bacterium, very few studies have been carried out in indigenous population.

The titers of the children who were evaluated in two Delta Amacuro State communities, were elevated according to the upper normal limit. No differences between the seroprevalence in the two communities were apparent. Seroprevalence is high and similar to that reported for other rural children populations in Venezuela (Piñero et al. 2000, Ortiz et al. 2001), and other countries (Bode et al. 1998, Elitsur et al. 1998, Torres et al. 1998). This is important since it has been reported that high titles are associate with a lesser likelihood of gastric carcinoma compared to low titer (Fujioka et al. 2001).

On the other hand, average value of the total secretory IgA levels was significantly lower than that found in groups of children from other rural communities of nonindigenous Venezuelans (Ortiz et al. 2000) and also significantly lower than in healthy children without any gastrointestinal pathology. With regard to mucosal immunity, it is clear that local IgA antibody plays a primary role en protection against foreign organisms (Goto et al. 1999). Therefore, deficiencies in the production of this antibody could be an indicator of damage of mucosal tissues. The environmental hygienic and socio-economic conditions of these children are low and they are permanently exposed to a variety of infections which compromise the gastrointestinal mucosal tissue, it is possible that there may be immunological alterations of the gastrointestinal tract. This effect could generate deficiencies of secretory $\operatorname{IgA}$ production or it may inhibit the exposure of Th2 cells to luminal antigens, which favor the positively selected response of IgA antibodies (Ernest et al. 1999). Thus alterations of regulatory mechanisms of the immune response could direct it towards a chronic inflammatory process of the gastric mucosal tissue. In addition, is possible that there may be some ethnic susceptibility effect.

No differences were found in the levels of specific secretory IgA to $H$. pylori between communities. Nevertheless, the values are above the cut-off point established in previous studies (Ortiz et al. 2000), suggesting the development of a local specific immune response through the production of secretory IgA to $H$. pylori antibodies. It has been reported that during $H$. pylori infection, levels of local and specific IgA to $H$. pylori antibodies increase (Wyatt et al. 1988, Taylor \& Blaser 1991). When comparing both communities, we found that the mean age of children from the Playa Sucia

TABLE II

Immunological results in children from two communities in Delta Amacuro State

\begin{tabular}{|c|c|c|c|c|}
\hline Community & $\begin{array}{l}\text { Total sIgA } \\
\text { (OD) }\end{array}$ & $\begin{array}{l}\text { sIgA to } H . \text { pylori } \\
\text { sIgA (OD) }\end{array}$ & $\begin{array}{l}\text { H. pylori seroprevalence } \\
\text { IgG } \% \text { positivity (titers) }\end{array}$ & $\begin{array}{l}\text { H. pylori antigens in } \\
\text { feces } \% \text { positivity }\end{array}$ \\
\hline $\begin{array}{l}\text { Isla Misteriosa } \\
(\mathrm{n}=38)\end{array}$ & $0.50 \pm 0.25$ & $0.48 \pm 0.25$ & $\begin{array}{c}21 \\
518 \pm 246\end{array}$ & $95^{b}$ \\
\hline $\begin{array}{l}\text { Playa Sucia } \\
(\mathrm{n}=60)\end{array}$ & $0.73 \pm 0.19^{a}$ & $0.47 \pm 0.19$ & $\begin{array}{c}38 \\
978 \pm 657^{b}\end{array}$ & 10 \\
\hline $\begin{array}{l}\text { Isla Misteriosa and Playa Sucia } \\
(\mathrm{n}=98)\end{array}$ & $0.64 \pm 0.25$ & $0.47 \pm 0.22$ & $\begin{array}{c}38 \\
828 \pm 583\end{array}$ & 55 \\
\hline $\begin{array}{l}\text { Value reference }{ }^{c} \\
(\mathrm{n}=50)\end{array}$ & $1.05 \pm 0.13$ & $0.116 \pm 0.103$ & $\begin{array}{c}- \\
135 \pm 52\end{array}$ & - \\
\hline
\end{tabular}

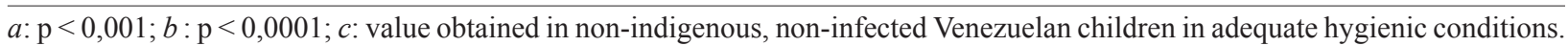


community was higher, and this could be one of the factors which explains why the levels of total secretory IgA and the titers of IgG to $H$. pylori were significantly higher than those found in children from the Isla Misteriosa community. In fact, it has been observed that the development of immunological memory and antibody titers progressively increase with age (Graham et al. 1991). We also found a higher percentage of children with fecal $H$. pylori antigens in the Isla Misteriosa community, which suggests that probably there are more children with recent infection in this population.

Regarding the socio-economic and cultural characteristics, the communities studied belong to Warao lineage and they present a high proportion of homes in a state of poverty, considering the inadequate hygienic conditions and the low family incomes, insufficient to cover the amounts needed for feeding the family.

Environmental conditions can significantly influence the general state of health of human beings, modulating the immune response (Ortiz et al. 2000) and high rates of H. pylori infection being associated with low socioeconomic status, high densities of living and poor hygienic conditions (Mitchell \& Mégraud 2002). Even if it is true that both communities belong to the Warao lineage and their geographical characteristics are similar, it should be also considered that Playa Sucia is a community which has been organized through a pilot program sponsored by the Regional Environmental Sanitation Direction of the Ministry of Health and Social Development of Venezuela since 1998. This program has implanted policies which improve living and environmental sanitation conditions. On the contrary, in the Isla Misteriosa community the hygiene and sanitation conditions are very deficient, the dwellings are primitive lake dwellings built on the riverbanks themselves, where there are marshes and swamps. This produces optimal conditions for the development of microorganisms and other infectious agents, generating a permanent infection source for its inhabitants, increasing the infection risk and therefore the damage to the gastrointestinal mucosal tissue. Even though the $H$. pylori transmission mode is not well established, fecal-oral and oral-oral modes of transmission have been suggested (Grübel et al. 1998) and intrafamilial transmission is important on the acquisition of infections (Miyazaki et al. 2002, Taneike et al. 2001). H. pylori has been cultured from vomitus, saliva, and diarrheal stool (Smith \& Parsonnet 1998). This study indicate that these communities present a high prevalence of $H$. pylori infection and that the hygienic conditions can influence the prevalence of the infection and may increase the risk of damage to the gastrointestinal mucosal tissue, influencing the course of the infection. It is important to continue studies in this type of community where infections are recurrent and the damage to the gastric mucous tissue can become a chronic problem generating a permanent immunological challenge as well.

\section{ACKNOWLEDGEMENTS}

To Dr Marian Ulrich and Dr Mario Sanchez Borges for reviewing the manuscript. To the local authorities of Delta Amacuro State. Mrs Niria Zabaleta and Lourdes Becerra collaborated in the evaluation of the children. To Warao indigenous populations for allowing us to enter and participate in their communities.

\section{REFERENCES}

Bode G, Rothenbacher D, Brenner H, Adler G 1998. Variation in the ${ }^{13} \mathrm{C}$ - urea breath test value by nationality in Helicobacter pylori-infected children. Scand J Gastroenterol 33: 468-472.

Brenner H, Rothenbacher D, Bode G, Dieudonne P, Adler G 1999. Active infection with Helicobacter pylori in healthy couples. Epidemiol Infect 122: 91-95.

Covacci A, Falkow S, Berg D, Rappuoli R 1997. Did the inheritance of a pathogenicity island modify the virurence of H. pylori? Trends Microbiol 5: 205-208.

Elitsur Y, Short JP, Neace C 1998. Prevalence of Helicobacter pylori infection in children from urban and rural West Virginia. Dig Dis Sci 43: 773-778.

Ernest PB, Song F, Klimpel GR, Haeberle KB, Bamford SE, Crowe G, Ye G, Reyes VE 1999. Regulation of the mucosal immune response. Am J Trop Med Hyg 60: 2-9.

Falk PG, Syder A, Guruge J, Kirschner D, Blaser M, Gordon J 2000. Theoretical and experimental approaches for studying factors defining the Helicobacter pylori-host relationship. Trends Microbiol 8: 321-329.

Fujioka N, Fahey MT, Hamada GS 2001. Serological immunoglobulin $\mathrm{G}$ antibody titers to $H$. pylori in Japanese Brazilian and non-Japanese Brazilian gastric cancer patients and controls in São Paulo. Jpn J Cancer Res 92: 829-835.

Goto T, Nishizono A, Fujioka T, Ikewaki J, Mifune K, Nasu M 1999. Local secretory immunoglobulin A and postimmunization gastritis correlate with protection against Helicobacter pylori infection after oral vaccination of mice. Infect Immun 67: 2531-2539.

Graham DY, Malaty HM, Evans DG, Evans DJ, Klein PD, Adam E 1991. Epidemiology of Helicobacter pylori in an asymptomatic population in the United States. Effect of age, race, an socioeconomic status. Gastroenterol 100: 1495-1501.

Grübel P, Huang L, Masubuchi N, Stutzenberger F, Cave D 1998. Detection of Helicobacter pylori DNA in houseflies (Musca domestica) on three continents. The Lancet 352: 788-789.

Lowry O, Rosebrough N, Farr A, Randall R 1951. Protein measurement with the folin phenol reagent. $J$ Biol Chem 193: 265-275.

Ma J, You W, Gail MH, Zhang L, Blot WJ, Chang Y, Jiang J, Liu W, Hu Y, Brown LM, Xu G, Fraumeni JF 1998. Helicobacter pylori in a longitudinal study of New Zealanders at ages 11 and 21. Aust NZ J Med 28: 585.

Mitchell H, Mégraud F 2002. Epidemiology and diagnosis of H. pylori infection. Helicobacter 7: 8-16.

Miyazaki, Kato M, Takata T, Une H 2002. Intrafamilial transmission of Helicobacter pylori: the association between a parent and an offspring with respect to the presence of anti-CagA antibody. J Infect Chemother 8: 70-75.

Ortiz D, Cavazza ME, López T, Ávila M, Lecuna V, Correnti M, Perrone M 2000. Determinación de los niveles de IgA secretora específica anti-Helicobacter pylori en saliva en población venezolana. Enfermedades infecciosas y microbiología X Congreso de la Asociación Panamericana de Infectología 21, p. 38.

Ortiz D, Daoud G, Daoud N, Cavazza ME, Urrestarazu MI, Rodríguez N, Correnti M, Ávila M 2001. Evaluación de los niveles de IgA secretora en saliva de niños con Helicobacter pylori. Arch Venezol Pueric Ped 65: 44-49.

Piñero R, Plasencío A, Ávila M, Urrestarazu MI, Serrano N, 
Correnti M, Cavazza ME 2000. Helicobacter pylori en niños de "EL Clavo", una población rural venezolana. Gen revista de la Sociedad Venezolana de Gastroenterología 54: 1217.

Rothenbacher D, Bode G, Berg G, Knajer U, Gonser T, Adler G, Brenner H 1999. Helicobacter pylori among preschool children and their parents: evidence of parent-child transmission. J Infect Dis 179: 398-402.

Smoat BL, Kelly PW, Taylor DN 1994. Seroprevalence of Helicobacter pylori infection in a cohort of US Army recruits. Am J Epidemiology 193: 513-9.

Smith K, Parsonnet J 1998. Bacterial infections of humans. In AS Evans, PS Brachman, Epidemiology and Control, p. 337353.

Taneike I, Tamura Y, Shimizu T, Yamashiro Y, Yamamoto T 2001. Helicobacter pylori intrafamilial infections: change in source of infection of a child from father to mother after eradication therapy. Clin Diagn Laboratory Immunol 8: 731-739.

Taylor DE, Blazer MJ 1991. The epidemiology of Helicobacter pylori infection. Epidemiol Rev 13: 42-59.

Torres J, Leal-Herrera Y, Perez-Perez G, Gomez A, CamorlingaPonce M, Cedillo-Rivera R, Tapia-Conyer R, Muñoz O 1998. A community-based seroepidemiologic study of
Helicobacter pylori infection in Mexico. J Infect Dis 178: 1089-94.

Torres J, Pérez-Pérez G, Goodman K, Atherton J, Gold B, Harris P, Madrazo-de la Garza A, Guarner J, Muñoz O 2000. A comprehensive review of the natural history of Helicobacter pylori infection in children. Arch Med Res 31: 431-469.

Vaira D, Miglidi M, Mule P, holton J, Menegatti M, Vergura M, Biasco G, Corte R, Logan RP, Barbar L 1994. Prevalence of peptic ulcer in Helicobacter pylori positive blood donors. Gut 35: 309-312.

Vorobjova T, Grünberg H, Oona M, Maaroos HI, Nilsson I, Walström T, Covacci A, Uibo R 2000. Seropositivity to Helicobacter pylori and CagA protein in schoolchildren of different ages living in urban and rural areas in southern Estonia. Eur J Gastroenterol Hepatol 12: 97.

Wyatt JI, Rathbone BJ 1988. Immune response of the gastric mucosa to Campylobacter pylori. Scand J Gastroenterol (Suppl.) 142: 44-49.

Wotherspoon A, Doglioni C, Diss T, Pan 1, Moschini A, de Boni M, Isaacson P 1993. Regression of primary low-grade B-Cell gastric lymphoma of mucosal-associated lymphoid tissue type after eradication of Helicobacter pylori. Lancet 342: 575-577. 